\title{
STAR BRIDE MARRIES A COOK: THE CHANGING PROCESSES IN THE ORAL SINGING TRADITION AND IN FOLK SONG COLLECTING ON THE WESTERN ESTONIAN ISLAND OF HIIUMAA. II
}

\author{
Helen Kõmmus, Taive Särg
}

\begin{abstract}
This article is the second part of a longer writing about Hiiumaa older folk songs. Relying on the critical analysis of the folk song collections, which represent the heritage of the second biggest island in Estonia, Hiiumaa ${ }^{1}$, as well as on manifold background information, the character of the singing tradition in the changing social and cultural context is drafted. The first part of the study was published in the previous, 67th volume of Folklore: Electronic Journal of Folklore. It focused on the history of folk song collecting in Hiiumaa (from 1832 to 1979) and analyzed the representativeness of the collected material.

The present article highlights the specific features of Hiiumaa older folk songs, which represent the historical styles of Baltic-Finnic alliterative songs: regilaul, transitional song, and archaic vocal genres. The settlement history of Hiiumaa is studied and related to the putative processes in folk song tradition. The analysis reveals regional western Estonian features and the process of historical changing, especially a pervasive impact of bagpipe music in Hiiumaa songs. The singing tradition has been influenced mainly by cultural contacts with the Estonian and Swedish population on Estonian islands and the western coast, and also by the contacts of local sailors.
\end{abstract}

Keywords: Estonian Swedes, folklore collection, Hiiumaa, regilaul, traditional music

\section{INTRODUCTION}

The collection and study of older folk songs has been one of the main fields of interest in European and Estonian folkloristics since the nineteenth century. Despite this, Hiiumaa older folk song tradition has not attracted much attention until now. The present study, published in two consecutive volumes of Folklore: Electronic Journal of Folklore, is an early bird in this field. Our work is based on the folklore collections that are mostly stored in the Estonian Folklore Archives (EFA), but also partly in other archives as well as published in books. As it was proved in the first part of the study (Kõmmus \& Särg 2017), 
the folk song collections contain not extensive, but still representative material from Hiiumaa folk song tradition (altogether about 1430 variants of older folk song lyrics and 280 melodies) since around the mid-nineteenth century. The diminishing percentage of regilaul recordings over the last 150 years reflects the disappearing of this tradition, while the numbers for other older song genres (transitional songs and archaic vocal genres) in the folklore collections are more dependent on the collection goals.

The main goal of the present article, which forms the second part of our study, is to analyze the specific local stylistic features of Hiiumaa older folk songs and the putative ways of their development against the background of local settlement history and cultural contacts. The article also contributes to the discussion about why there are no big collections of Hiiumaa old folk songs, especially regilaul songs. A closer analysis of the song texts, melodies, and contextual information was carried out in order to understand whether regilaul as a style had died out in the nineteenth century or had never properly spread or developed in Hiiumaa - perhaps because of the cultural impact of the local Swedish community or other ideological, historical or cultural factors. The results of the study may shed light upon the regional developments of the Baltic-Finnic folk song tradition and the more extensive cultural processes in the Baltic Sea area.

\section{BETWEEN OLDER ALLITERATIVE FOLK SONG STYLES AND MORE MODERN, END-RHYMED STANZAIC FOLK SONG}

The song styles and genres as well as the ties between them are characterized below in order to draft an overall picture of the changing Hiiumaa singing tradition. The only earlier attempt to study Hiiumaa folk songs, Harri Otsa's manuscript Hiiumaa uus rahvalaul ('The modern folk song of Hiiumaa', 2001) focuses on the newer tradition, which overlaps the border areas of our research material and questions. Despite the problems with the methods, Otsa's work contains good observations and brings out the essential about Hiiumaa tradition - a vivid modernization process around the late nineteenth and early twentieth centuries, and especially the development of male repertoire from regilaul style to newer "polka-rhythmic song" (ETMM, M 221: 1/15: 41, etc.).

\section{Regilaul}

Hiiumaa belongs to the bigger western Estonian dialectal and cultural region. According to comparative metrical analyses made by Mari Sarv for the twelve 
Estonian regilaul areas, the western Estonian ${ }^{2}$ regilaul has a syllabic-accentual meter rather than a quantitative Kalevala-meter. As compared to the other eleven areas, Hiiumaa regilaul has the most striking features of the syllabicaccentual meter - the least number of broken verses $(5 \%)$; the second biggest number of "accentual verses" (in which, contrarily to Kalevala-meter, a word initial short syllable fills a strong position, 34\%); the biggest number of both shorter verses (with unfilled last verse position, 34\%) and verses with two syllables in one position (36\%) (Sarv 2008: 26-27, 39).

Lyrical songs. The lyrical songs tend to have modernized features in Hiiumaa, as is represented in Example 2. This regilaul has the following formal poetic features that occur in both - regilaul and transitional style:

1) some verses are shortened for the use of shortened contemporary words, instead of archaic regilaul word forms, so a syllable is dropped (e.g. in verse 21: mees < meesi), ${ }^{3}$ or the verse is already built according to the shortened structure $(49,50)$;

2) two syllables often occur in one position (preferably in the first two positions, but also in others) if there is a need to fit more than eight syllables in a verse and/or match word stresses to metrical stresses (verses $2,5,6$, etc.);

3) syllable quantity has not been relevant for singers at recreating the verses, although some verses might reflect the earlier quantitative system (e.g. remnants of the placement of a word initial short syllable on the metrically weak 6 th position might be seen in some verses, such as 19);

4) several two-line parallelism groups, resembling an end-rhymed couplet, while the end-rhymes are rarely perfect (49-50 kukuta-lukuta), but often impure (1-2 minna-panna, 6-7 pöllalt-kallalt) or identical (25-26 poolt); the difference from a consistent end-rhymed form is that couplets occur irregularly ( 5 is a single verse, $46-48$ is a three-verse group with an identical rhyme pääle or a parallelism group) and the content of a verse pair resembles a parallel structure, i.e., it expresses and complements the same poetic motive (e.g. 3-4, 6-7, etc.);

5) alliteration (marked in bold in verses 1-3); also a tendency to have the same vowels in the stressed syllables.

Example 2 is a Hiiumaa men's song about the conflict between a manor overseer and a serf. The text contains stereotypic regilaul formulas and motives, the main plot belongs to the well-known regilaul type Kubjas ja teomees ('The overseer and the serf'), represented in the EFA by several variants from Hiiumaa and 
other regions (Tedre 1969-1974, type No. 1413). Due to the use of alliteration, parallelism, 8-positional verse, and the formulaic language and typical plot of the regilaul, the song variant has been classified as a regilaul - despite certain modernized poetic means - both by the authors of this research and an anonymous EFA archivist.

\section{Example 2.}

Uidut-tuidut teule minna,

ei pole pasteld jalga panna, vanad pastlid paikamata,

uued nahad parkimata.

${ }^{5}$ Läksin aga hobusid otsima. Musta sain mina Moore pöllalt,

halli kaaranaabri kallalt, ise aga astusin halli selga, musta vetsin kää körva,

${ }^{10}$ siis läksin möisa teutoa ede. [---] Hakkasin kubjast paluma:

20 "Anna mulle veikene livvatükk!"

Kubjas oli kuri kurat mees, möötis moole suure souetüki, seda mina kündsin loupe öhta, loupe öhta eige hilja.

${ }^{25}$ Junkur tuleb turu poolt ja kubjas Kiimu körtsi poolt. [---]

${ }^{45}$ Junkur aga hakkas jooksema:

jölk jähi maha sülla pääle, teine turu trummi pääle,

kolmas koja trepi pääle; siis sai tuba kukuta, ${ }^{50}$ ja ukse kinni lukuta.
Uidut-tuidut, to go to the manor work, no leather shoes to put on, the old leather shoes have not been patched, the new skins have not been tanned yet.

${ }^{5}$ I went to look for the horses. I got the black one from the Moore field, I got the grey one at the oat stack, I mounted the grey one, I took the black one by the reins, ${ }^{10}$ then I went to the manor office. [---] I began to plead with the overseer: 20 'Give me a little piece of sand [to plough]!'

The overseer was an evil devil man, he measured mea large piece of clay, I ploughed it on Saturday night, on Saturday very late at night.

${ }^{25} \mathrm{~A}$ junker came from the market and the overseer from Kiimu tavern. [---]

45 The junker started running, though:

a trace left behind on the bridge, the second left on the market culvert, the third on the entrance stairs; and then he could fall into the room, ${ }^{50}$ and lock the door.

H II 41, 10/2 (3) < Reigi p. - Peeter Reikmann (1889) 
Social antagonism has been a prolific topic in the whole Estonian regilaul tradition. We can suggest that song types represented by numerous and manifold variants of mixed stylistic features were in the process of changing, and were popular in the folklore collecting period or somewhat earlier. They were often sung and so, step by step, were modernized according to the changing taste. As peasants kept working on manors in Hiiumaa until the late nineteenth century, ${ }^{4}$ the songs were likely in active use until that time. Other popular topics in Hiiumaa lyrical songs are village life and the relationships between maidens and young men.

The lyrical regilaul songs were usually sung to newer two-line melodies, their ambitus ranged from sixth to octave or more, and they had an even-numbered meter without noticeable deviances. The transcription No. 120 in Example 3 represents a typical men's song melody; its lyrics have quite a regular regilaul form.

Example 3. The manuscript of Peeter Süda, EÜS II 822 (1905); No. 120 regilaul Halb naine ('The bad wife'); No. 121 waltz Ilus tüdruk ('The pretty girl'); No. 122 labajalg $^{5}$ dances of a wedding ritual played on bagpipes, the last one with singing. I. Pruudi sisse kutsumine ('Asking the bride in'), II. Waka jägamise lugu ('The piece for distributing the bride's gifts'), III. Pulma lõpp ('The end of the wedding'). ${ }^{6}$

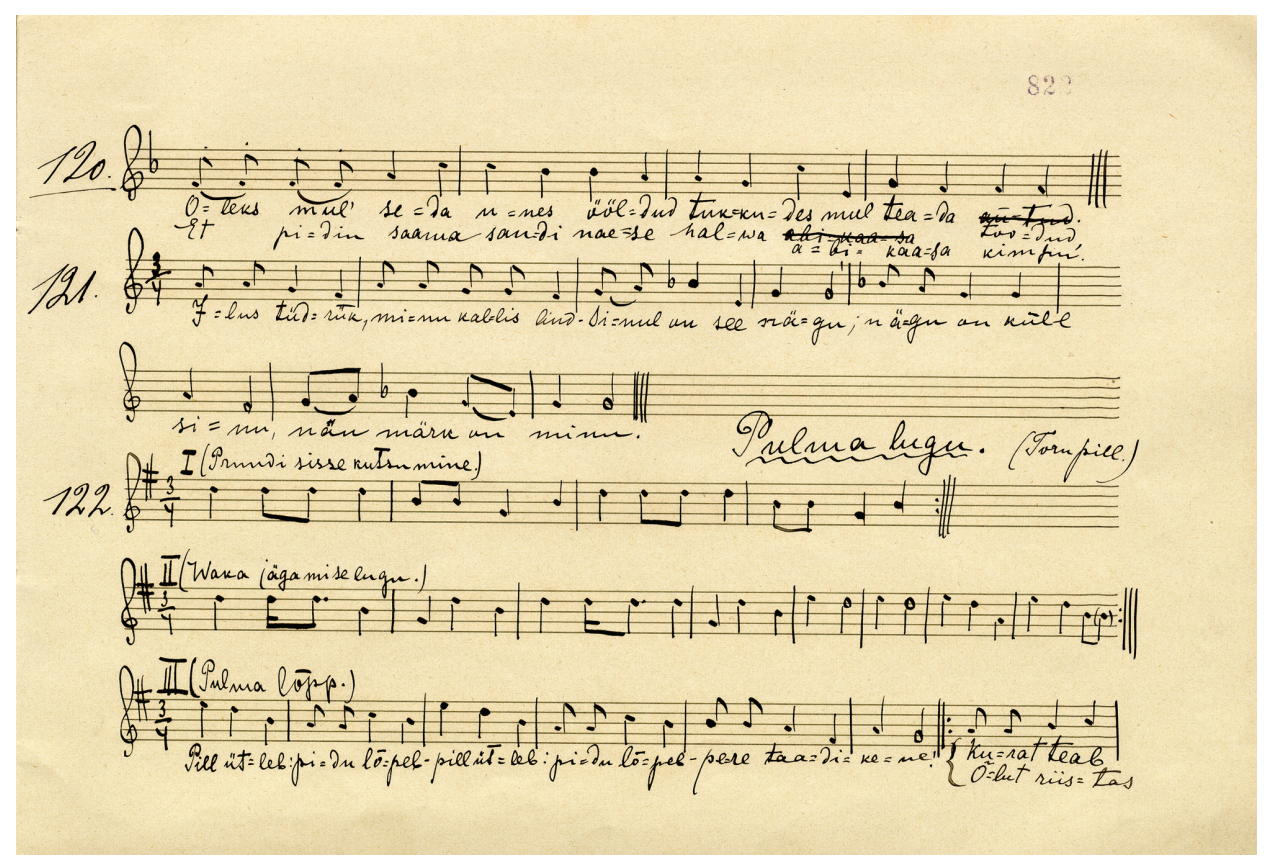


Lyroepic songs. A manifold but not rich collection of lyroepic songs (56 variants) ${ }^{7}$ includes some poetic and wholesome examples, such as Tähemõrsja ('The star's bride'), Venna sõjalugu ('The brother's war tale'), Peiu laev ('The groom's ship'), Lunastatav neiu ('The maiden for ransom'), and other songs. This tradition, however, bears signs of decline because several song types are represented just as fragments in contaminations, for example, a variant of Suur tamm ('The big oak') has been added to a song about village life (Example 1 in part 1), and the variants of Hobuse otsimine ('Searching for the horse') occur only as a motif of Kubjas ja teomees ('The overseer and the serf') (Example 2). Some songs feature a new humorous attitude; for example, in Tähemõrsja ('The star's bride') the star in the role of a groom has been replaced by a young chef:

\section{Example 4.}

[---] Ta läks kokapoisile.

Sääl sai pehmet rooga sü̈̈a, kuldsest katlast kohvi juua.
She married a young chef. There [she] got soft food to eat, to drink coffee from a golden kettle.

EÜS II 977/8 (131) < Reigi p. - Peeter Süda, Voldemar Quarnström $<$ Andrus Mann, 65 (1905)

Several oldest Hiiumaa examples of lyroepic songs, published by Gottlund (1832) and Lönnbohm (alias Mustonen) (Lönnbohm 1893) contain a smaller amount of transitional features. Example 5, Kass kaevus ('The cat in the well'), has western Estonian accentual-syllabic regilaul meter with typical features: plenty of divided positions (verses 1-3, 5-14, etc.), but not many empty 8th positions after shortened word forms (e.g. 13 kuijemast < kuijemasta). The quite regular 8-positional structure and the prolonged vowel instead of a disappeared ending (9 kuijemaa < kuijemaie) refer probably to a recent drop of the final syllable. The tendency to form end-rhymed verse pairs, perhaps suggested by a two-line melody, is to a certain extent reflected in two-line parallel groups (1-2 mieste-koirukeste, 5-6 maata, etc.).

\section{Example 5.}

Oli mina muista nuoru mieste. Oli mull kolmu koirukeste: yks oli Irvi, teno Erve, kolmas Muru, musta litsi.
I was a young man ages ago.

I had three dogs: one was Irvi, another Erve, the third was Muru, a black slut. 
${ }^{5}$ Niet söitset mole suota-maata,

ma isse marsi sen määtä-maata.

Ne töi mull tuhat tui lintu,

sata santti jäneksä-poika. Ma pani lihat kuijemaa,

${ }^{10}$ ma pani maut mautlemaa.

Vanna kass oli kiimas silma, vanna kass oli laija kämmä.

Söi minun lihat kuijemast, söi minun maut mautlemast. [---]
5 They were running the boggy land for me, I myself was marching along the tufty ground.

They brought me a thousand doves, a hundred crippled young hares. I set meats to dry, ${ }^{10}$ I set sausages to lie. An old cat had lusty eyes, an old cat had large paws. It ate my meats that were drying, it ate my sausages that were lying. [---]

(Gottlund 1832: 184-187)

The variants of lyroepic songs are quite rare and fragmentary in newer collections (from the twelve variants collected after 1906, only four are longer than ten verses; no variant has been added after 1939). A single melody, noted with a lyroepic text, ${ }^{8}$ is a four-line tune of functional-harmonic dimension, probably simultaneously used for newer end-rhymed songs of stanzaic structure. So lyroepic songs declined earlier, perhaps around the mid-nineteenth century.

Ritual songs. Wedding songs. The existence of ritual regilaul songs might be essential to answer the question whether the vivid regilaul tradition once existed in Hiiumaa. The ritual songs are connected to the context and activity, so it was not likely that many of them spread out via casual contacts. From that point of view, it is interesting to recognize the ample remnants of wedding song tradition. There are at least 75 variants (five with melodies) of wedding songs, including even longer cycles, which reflect the course of the ritual, ${ }^{9}$ mainly from eastern Hiiumaa - the small Kassari Island and its surroundings. ${ }^{10}$

It was surprising that wedding descriptions, as far as we managed to read them, did not mention regilaul singing, but only dance songs and church chorals as a part of ritual and entertainment. Singing in weddings likely disappeared in the mid-nineteenth century, but the songs survived longer in people's memories. All the song examples were collected between 1877 and $1939,{ }^{11}$ the oldest singer whose year of birth was known was born in 1817, the youngest in 1896 . 
The regilaul wedding songs are in quite a traditional style, so they perhaps disappeared from active use before the transitional features became more fashionable in regilaul. Example $6 \mathrm{~b}$ represents the dialogue between groom's and bride's singers at the arrival at the bride's home: Tare teretus (verses 1-3) / Neiut pole kodus (4-8) / Imemaa (9-23) / Kust teadsid siia tulla? (24-27) / Sirgujäljed (28-32) / Kas on hobust neidu viia? (33-35) / Kosjahobu söötmine (36-60) ('The greeting of the house' / 'The maiden is not at home' / 'Wonderland' / 'How did you know to come here?' / 'Bird's footprints' / 'Have you got a horse to take the maiden?' / 'The feeding of a wooing horse'). The lyrics have a western Estonian syllabic-accentual regilaul meter with some typical shorter lines (5, 10, etc.), doubled syllables (3, 7-9, etc.), and even some archaic unshortened words with an ancient infinitive ending -maie (13-16).

The archaic variable melody (Example 6a) of speech-like intonation, short one-line structure and a narrow ambitus, recorded in three wedding song variants from Kassari (in 1905, 1933), belongs to the ancient northern Estonian wedding song tradition. There is no prolongation at the verse ends, characteristic of the old northern Estonian melodies known also in Muhu and Saaremaa (Oras 2001; Rüütel 2015a, 2015b). One two-line wedding song melody resembles a typical Mustjala tune from Saaremaa, ${ }^{12}$ another has a newer unusual structure. ${ }^{13}$

Example 6. Wedding song cycle, sung when the groom's party is arriving at the bride's home: a) some verses, phonographed from Leena Elmi in 1933; b) fragments of lyrics, written down from Ann Maripuu in 1925. Both singers lived on the small island of Kassari, eastern Hiiumaa.

a)
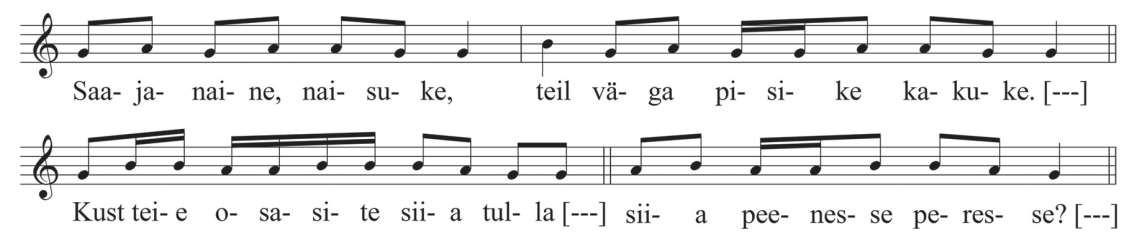

ERA, Fon 378 e < Pühalepa p., Kassari - Herbert Tampere < Leena Elmi, b. 1864 (1933)

b)

Sajanaine laulab: Tere Jumal siia tuppa, Maarja siia majasse! Püharist siia põrandale!
The best woman sings: Welcome, God, in this room, Maria in this house! The holy cross on this floor! 
Tüdrukud laulsid vastu:

Sajanaine, naisukene,

${ }^{5}$ mis te meile otsite?

Meie neiut pole kodus, neiu läks kaevust vetta tooma.

[---]

Sajanaine naisukane,

${ }^{25}$ kus sa osasid siia tulla, siia suuresse sugusse, siia laiasse lautsisse?

Sajanaine:

Siit aga tulid siili jäljed,

kaudu kaske kassi jäljed,

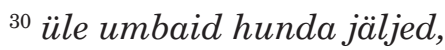

üle niidi nirgi jäljed,

üle põllu põdra jäljed.

Tüdrukud:

Sajanaine naisukene, kas sul seda hoosta õues,

${ }^{35}$ kes sulle neiu ära veab?

Sajanaine:

Nägin neidu kasvavat, maast kui marja tõusevat.

Hakkasin hoosta hoidema [---]
The maidens replied singing: Best woman, dear woman, ${ }^{5}$ what are you searching for? Our maiden is not at home, she went to take water from the well. [---]

Best woman, dear woman,

${ }^{25}$ how did you know the way here, to the big family, to the large in-laws' tribe?

The best woman:

The hedgehog's footprints came from here, the cat's footprints [came] through the birches,

${ }^{30}$ the wolf's footprints over the yard, the weasel's footprints over the meadow, the moose's footprints over the field.

The girls:

Best woman, dear woman, have you got a horse in the yard, ${ }^{35}$ which can take the maiden away?

The best woman:

I saw the maiden growing up, rising like a berry from the ground.

I started to take care of the horse [---]

E, StK 30, 80/3 (69) < Käina p., Kassari - Selma Perv < Ann Maripuu, $83(1925)$

\section{Archaic vocal genres}

Hiiumaa is represented in the EFA with 381 text variants (95 of them are soundrecorded and 6 are provided with melody transcriptions) of various archaic vocal genres: mostly imitations of different sounds (114 variants, dance songs 
labajalg excluded), incantations (89), ${ }^{14}$ chain songs (59), and older children's songs (82), but also rarities, for example, some threshing songs. The newer versions of the same genres are featured mainly by new verses of different styles or end-rhymes or singing to triple meter, which have been classified as transitional songs.

The most elementary sound imitations are the onomatopoetic formulas that add emotionality and perceptibility to speech. They occur in talks about music (e.g. songs are called umpa-umpad,,$^{15}$ a hand harmonica sound is characterized as horr-horr-horr-horr... ${ }^{16}$ ) and in song lyrics. The hiiu waltz is described through sounds: "...[it meant] a quite silent moving; it was done this way: sauhh-sauhh-sauhh, sauhh-sauhh-sauhh" ${ }^{17}$ Although concise expressions, they have a musical character, for instance, the previous quotation lets us recognize the dance of rustling feet in triple meter. Sometimes some nature sound imitations might have an essential role in a folktale; for instance, the sound of cutting, followed by the fall of a tree, forms a humorous final point: litt-löterdi, litt-löterdi, laatsti $1^{18}$

It is difficult to specify starting from where such a musical expression can be considered as a folktale song - a special genre known by many cultures (Rüütel 1998). Fairy tale songs occur in the function of emotional speech in Seto fairy tales (Salve \& Sarv 1987). The only Hiiumaa folk song that matches a certain fairy tale type (ATU 720) and a regilaul type is Vaeslaps käoks ('The orphan turns into a cuckoo'). A variant of the song ${ }^{19}$ has been transcribed with a cuckoo's sound imitation in the refrain from Gustav Lauri in 1905 (see Example 7).

\section{Example 7.}

Kuku, kuku, kiga, käga, kaga, kägu.

Isa suri mul ära.

Ema suri mul ära.

Kuku, kuku, kiga, käga, käga, kägu. (2x)

Konnad koristas'd mu kondid kollase lõnga peale kokku.

Kuku, kuku kiga, käga, käga kägu.
Refrain: Cuckoo, cuckoo, kiga, käga, kaga, kägu [cuckoo].

My father died.

My mother died.

Refrain: Cuckoo...

Frogs collected my bones onto the yellow yarn.

Refrain: Cuckoo...

EÜS II 878 (23) (text); EÜS II 789 (20) (melody) < Pühalepa p., Kõpu v. Peeter Süda, Gustav Lauri < Gustav Lauri, 25 (1905) 
A characteristic fact about changes in folk song tradition is that in 1979 Lauri's daughter, Elli Küttim, sang the same long refrain to a French herding song, which has been published in the form of a canon with a refrain ' $k u k u$ ' in several songbooks. Küttim claimed she learned the song from her father. ${ }^{20}$ So the long cuckoo's sound imitation as a refrain was taken over for another song.

The bagpipe sound imitations, often combined with other poetic elements, were distinguished as a specific subgenre of transitional style because they functioned mainly as the labajalg dance songs with triple meter (cf. Rüütel 2012: 130).

The archaic children's song is, on the one hand, a stable genre due to its timeless function, and, on the other hand, a changing genre for being sung alone, less dependent on the group. Children's songs have accentual verse with a basic structure of 6-8 positions, the last case resembling regilaul. Here we once again have to admit to a slight subjectivity as some children's songs could be classified as regilaul. Incantations include mainly short magic texts for various tasks, like facilitating work, curing diseases, etc. There are also some magic texts that contain end-rhymes together with alliteration.

The first sound-recordings of Hiiumaa archaic genres were again made from Leena Elmi (b. 1864) in 1933; many of them were recorded in 1962 and 1979. So it became evident that the songs were persistently performed in their traditional way - by a single person in a rhythmic speech-like manner, while one melody was used for several songs of a similar function, for example, in Juuli Küttim's repertoire. ${ }^{21}$

\section{The transitional song styles}

The transitional songs of lyrical and lyroepic character share some poetic features of the regilaul. They are likely new creations or adaptations that tell stories about the events in village life, such as wooing trips, girls' affairs, as well as about sailors' and soldiers' life, and do not match any traditional regilaul type. Example 8 about sailors' life tends to have even fewer end-rhymes and contains more parallelism groups $(4-10,15-17)^{22}$ than some songs based on a certain regilaul type (cf. Example 2), but its meter, motives, topic, and vocabulary resemble regilaul to a smaller extent (1 is a stereotypic beginning verse, 11 resembles a verse from a transitional circle game Palgamaksmine ('Paying wages')). Its main plot can be divided into the parts titled Laevatöö (1-21) / Palju laevu (22-34) / Suure tuulega merel (35-62) / Laevahukk (63-79) ('Ship work' / 'Many ships' / 'On the sea with a strong wind' / 'Shipwreck'), the last two being the types of regilaul. So we have classified the song as a transitional one. 


\section{Example 8.}

Noored mehed, hellad vennad, kellel noored poisimehed: ärgega olge vastased. Küll teid pandaks tähele,

${ }^{5}$ sunnitaks teid sadamasse, ametit sääl antakse.

Saega puuse pannakse, haambrevarte vaadatakse, laevateed ${ }^{23}$ sul õpetakse, ${ }^{10}$ laeva külge pandaks käed. Kui pole rahul sellega, küllap siis soovitaks kroonule,

kroonu hirm on kuri kange.

Viiaks kroonu süllale,

${ }^{15}$ püss ja mõõk sul antaks kätte,

pannaks vahi putka ette;

püssil pannaks paijun otsa. [---]

Kliibri vallid leiate, ja taagli vallid leiate; teeme terveks ruulirattad, võtame sisse linalasti,

${ }^{75}$ linalasti, kanebilasti;

läävad sis laevad Liisapunti,

Liisapuntist Leegerpungi, Leegerpungist Portugali, Portugalist Portugü̈̈si.
Young men, dear brothers, who have got bachelors, don't be averse.

You will be noticed,

${ }^{5}$ forced to the port, given a job.

Set you with a saw into wood, a hammer's handle will be found for you, ship work will be taught to you, ${ }^{10}$ your hands will be put at the ship. If you won't be pleased with it, perhaps you will be suggested for the military service, the army's coercion is evil, strong.

You will be taken to the army's road,

${ }^{15}$ you will be given a sword and a riffle, you will be set in front of the sentry box, the bayonet will be set on top of the riffle. [---]

You will find jib's halyards, and you will find rig's halyards; we will repair steer-wheels, take in the linen-load,

${ }^{75}$ linen-load, cannabin-load; the ships will go to Liisapunt then, from Liisapunt to Leegerpung, from Leegerpung to Portugal, from Portugal to Portugüüs. ${ }^{24}$

H II 6, 235/8 (12) < Hiiumaa - Gustav Seen, Peeter Saul (1890)

The dance songs labajalg (or labajalavalss). Bagpipe music has had a strong impact on the western and northern Estonian singing tradition. The 
dance songs in triple meter, mainly sung to bagpipe pieces by the musician and/ or dancers, have been very popular in Hiiumaa at least since the nineteenth century: the earliest documentation of this was made in 1877 by Mustonen. The folklore expedition of the EFA to Hiiumaa in 1979 recorded more than 40 variants and proved that this song genre was still widely known. Our data contain 265 variants of labajalg song lyrics (included asemantic texts), 67 of them with a melody (41 sound recordings), and 3 melody transcriptions without lyrics. The local dance version is called (hiiu) waltz.

Several facts prove the existence of a close link between the bagpipe music and the abovementioned dance songs. Mustonen called the bagpipe songs "the remnants of the songs that are being trolled to the dance pieces instead of instrumental music or in addition to it ..." (Lönnbohm 1893: 2, 5) and he titled the chapter about dance song lyrics Pilliloud ('Instrumental music'; ibid.: 85-88) although no melodies were published. In Süda's collection the instrumental piece is titled with the first verse of a dance song, and some violin and bagpipe pieces have been added to the song texts (see Example 3) ${ }^{25}$

The labajalg song verses contain 3-6 syllables with 3 main stresses according to characteristic triple meter with several subdivisions. The poetic means might include both parallelism groups and end-rhymes, asemantic and semantic onomatopoetic bagpipe sound imitations as well as many weird words and repetitions. (The songs with triple meter that have consistent end-rhymes and stanzaic structures are not included here.) The large number of soundrecordings makes it possible to better understand the role of sound imitations; for instance, the seemingly pointless words like küliluu as well as the rest of the text is performed with different speed and timbres, matching the different devices of a bagpipe (Examples 9-10).

Examples 9-10. The dance songs labajalg, containing onomatopoetic syllables that imitate bagpipe sounds. ${ }^{26}$

\section{9)}
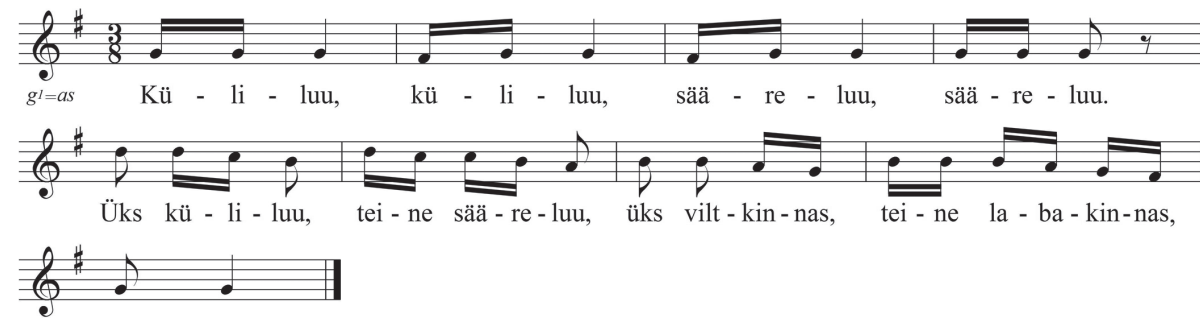

uh - huu! 
10)

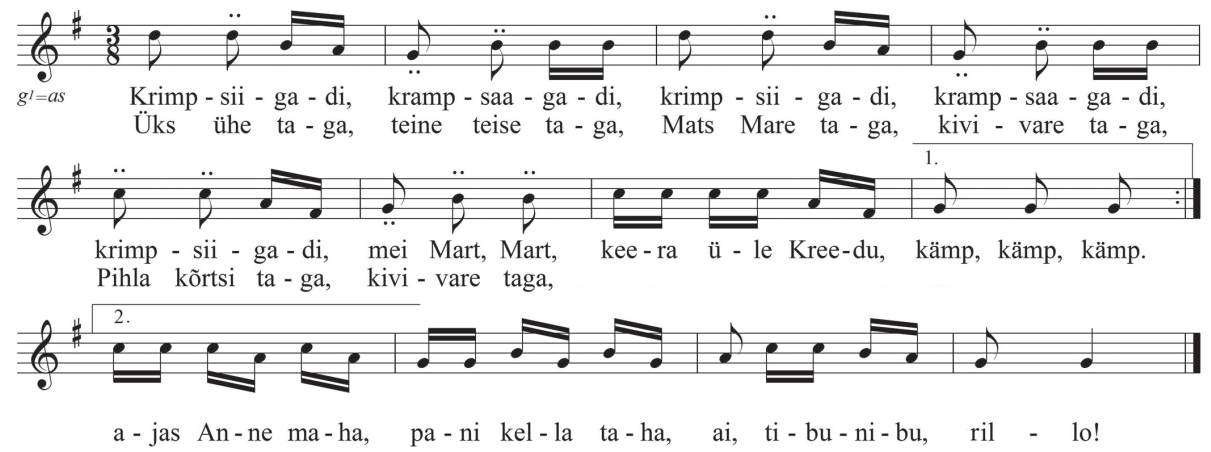

The labajalg style has often strikingly frivolous lyrics (Example 10); for instance, Mustonen (Lönnbohm 1893: 2) writes that several songs are quite "frisky and wanton" (vallattomia ja hurjamaisia); Süda asks whether to write down obscene songs in 1905 (Kõmmus \& Särg 2017: 103); Jansi blames Hiiumaa "amoral" folklore in 1922 (ibid.: 106-107); and Otsa (ETMM, M 221: 1/15: 64) does not publish the "improper" lyrics of two dance songs, written down in 1969 and 1973 respectively. The humorous and often erotic content is likely related to the songs' function as a part of weddings and entertainment.

The bagpipe songs well known all over Estonia are also represented in Hiiumaa; for instance, the joking Hiir hüppas ('The mouse jumped', Example 11b), but there is a rich choice of other songs, such as Ühe lae pealt teise lae peale ('From one ceiling to another ceiling'), Eht iidlane, ihu vaenlane ('A real Hiiumaa man, an enemy of his flesh'), and many others.

Bagpipe music also had its own purpose in rituals and at work. The labajalg dances and songs with bagpipe were essential at some stages of the wedding, such as giving thanks to the cook (Supimoori tants 'Soup woman's dance'), collecting money (Kotipoisi tants 'Sack boy's dance'), asking the bride in, the bride's dance, the end of the wedding (Example 3, No. 122), not to mention dancing as part of the party. The autumn calendar rituals mardisandid (Martinmas mummers) and kadrisandid (St. Catherine's Day mummers) are represented mainly with short fragmentary dance songs in Hiiumaa, while, conversely, the long cycle of this custom is the most numerously represented regilaul song type in the EFA from the rest of Estonia. Bagpipe music with short texts was also used in Hiiumaa to stimulate people when they worked in the field. ${ }^{27}$ 
Children's songs. Beginning in the eighteenth century, the modernization of children's songs probably ran side by side with similar processes concerned with other folk music genres in Hiiumaa. Both archaic and transitional versions of children's songs were in use during the twentieth century and were soundrecorded. While the lyrics were usually very short, the melodies gave valuable information about the singing styles of transitional children's songs - mainly in triple labajalg meter and in double meter.

The great number of children's songs in triple meter gives evidence of the pervasive impact of bagpipe music. As the children's songs had accentual meter and were related to movement, they fit well to dance rhythms; for example, the verses for bouncing a child on a knee, Sõit-sõit-sõit linna ('Go-go-go to town'), or for imitating baking, Tee pätsi! ('Make a loaf!'). Juuli Küttim has one descending melody with a triple meter for transitional children's songs and labajalg dances (Example 11).

Example 11. Children's song repertoire in 1979, recorded from Juuli Küttim: a) a children's amusement song Tee pätsi ('Make a loaf'), an archaic vocal genre that is adapted to a well known dance song melody, represented in the same example; b) a well known labajalg song Hiir hüppas ('The mouse jumped') with modernized humorous lyrics. ${ }^{28}$

a)

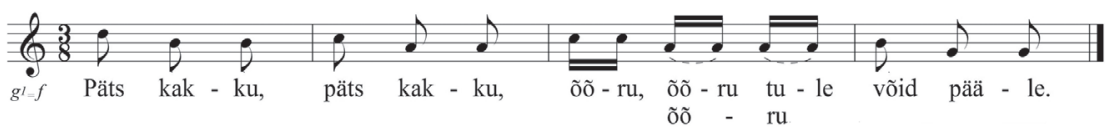

b)

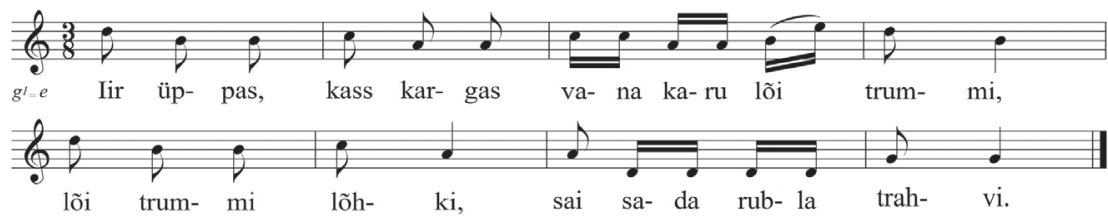

In summary, it could be said that the Hiiumaa song representations in the EFA collections show the changing processes in the vivid singing tradition during the last one and a half centuries. By its poetic features Hiiumaa regilaul belongs 
to the wider western Estonian tradition. The examples of lyroepic songs and wedding songs suggest that the tradition of older regilaul faded away around the mid-nineteenth century. Special for Hiiumaa was that a large part of the repertoire was modernized and (re)created locally, maybe in Hiiumaa or in the neighboring islands: the lyrical and lyroepic songs about village life, the soldiers' and sailors' lives, were rooted in regilaul. Many archaic vocal genres persisted in their traditional form. The strong impact of bagpipe music is reflected in a wide variety of dance songs and their important role in rituals and entertainments, as well as in many children's songs in triple meter.

\section{THE HISTORICAL AND CULTURAL CONTEXT OF HIIUMAA}

In order to better understand the processes in Hiiumaa folk culture, the ethnic background of its inhabitants, the settlement history and the cultural contacts are discussed below.

\section{Between Estonian and Swedish cultures}

The existence of mixed Estonian and Swedish population over a long period was special for the ethnic history of Hiiumaa: for hundreds of years these two equal and relatively big communities lived there side by side.

Geographically isolated and climatically harsh island conditions elicited normal dependence and active interaction between the two different ethnic groups. While other strong Swedish communities lived separately in Vormsi, Ruhnu, and Pakri, and tried to preserve their cultural uniqueness and personal rights, Hiiumaa Swedes assimilated slowly during 500 years and integrated the local Estonians as well. In most Hiiumaa families there are memories or legends about Swedish ancestors. Swedish families lived in Hiiumaa until the Second World War. On the western coast and the islands of Saaremaa and Muhu Swedish communities were smaller and became assimilated much more quickly than their compatriots in Hiiumaa.

The Swedes arrived at the Estonian coast and islands probably in the second half of the thirteenth century. They were first officially mentioned in 1470, when the German Teutonic order master Johann Wolthusen von Herse freed the Swedish commune in Hiiumaa from serfdom for a compensation of 20 Riga marks a year per village commune and issued them a freedom certificate. This document also contains hints about earlier agreements concerning the Swed- 
ish settlement in Hiiumaa (Hedman 2015: 801-802). The majority of Swedish inhabitants settled in Reigi Parish and the surroundings of what is now the town of Kärdla in northern Hiiumaa.

At the end of the fifteenth century, Hiiumaa was still named on geographical maps as insula deserta, an empty island. Data about the Estonian settlement in Hiiumaa was scarce and random until the mid-sixteenth century. The first official taxpaying statistics are from 1564 and permit an estimate of the permanent population at ca $2500-4500$ people. The Estonian peasants originated mainly from the neighboring islands of Saaremaa and Muhumaa and the western coast of Estonia. Hiiumaa's population rose tenaciously despite the repercussions of famine and pests, and was at its highest - ca 16,000 people - at the end of the nineteenth century. Throughout this period, the proportion of Swedes has generally been $10 \%$ of the population of Hiiumaa (Kaskor 2015: 787-797).

Owing to the Swede's active demands to protect their ancient rights as free peasants, they fell out of favor with the local German landlords. On the 20th of August 1781, the majority of the community, around 1000 Swedes from Kõrgessaare in Reigi Parish, were forced to leave their homes and were deported to Ukraine, where they established Gammalsvenskby village. Around 450 Swedes still stayed in Hiiumaa, in Reigi and Kärdla areas (Hedman 2015: 807-810).

According to German-Estonian historian Carl Rußwurm, the Swedes in Hiiumaa were bilingual already by the 1640 s. They spoke their mother tongue only at home and their folk traditions as well as national costumes differed very little from those of local Estonian peasants in the 1830s (Rußwurm 2015 [1855]: 137). Kaskor (2015: 794) claims that by that time the Swedish peasants had assimilated into the Estonian population.

The background of a bigger wave of Estonian settlers who emigrated to Hiiumaa from different parts of the western Estonian coast and islands during the sixteenth century was relatively heterogenic. People spoke various dialects and had different habits. Contacts between Estonian serfs, who had been forced by German landlords to move to unpopulated areas, were infrequent owing to geography - small villages were scattered along the long sea coast. Surviving and adapting to uninhabited landscapes were major problems for the newcomers. Because of different locational backgrounds and geographical dispersion, the common local identity of the Estonian population in Hiiumaa formed slowly. Musical culture was naturally brought along from the previous home. Locally specific songs formed during a longer domestication period, which could take two or three generations. 
The people of the Swedish community were indigenes in Hiiumaa from whom new settlers learned how to survive. Swedes as free peasants were probably highly respected among Estonian serfs and this prestige might have empowered their influence on Estonian folk culture. Swedish culture left its imprint on local folk costumes, handicraft, buildings, wedding and calendar customs and terms, folk music and language, etc.

Foreign impacts on folk songs are sometimes difficult to discover due to the difference in language. Mari Sarv has suggested, relying on the works about Estonian settlement and language history, that the language of Swedes or of the assimilated communities could have influenced the change in regilaul towards a more modern language and syllabic-accentual meter in Saare, Hiiu, and Lääne counties. In all these regions the more ancient song tradition has been maintained further away from Swedish communities (Sarv 2008: 85, 86; 2011). Our study proves that the oldest song tradition has survived in the eastern coastal regions of Hiiumaa and on Kassari Island.

Modernization processes similar to those in Estonian folk music also occurred in Swedish folk music where newer songs were borrowed from Finnish and Swedish seamen or learned from printed books in the mid-nineteenth century (Rußwurm 2015 [1855]: 462-463). The putative Swedish impact might have accelerated the musical change from Estonian older to newer songs in the eighteenth and nineteenth centuries. The direct footprints of the Swedish language occur in some children's songs, such as a type of Mutter keetis moosi ('Mutter [Mother] boiled jam'), or the fully Swedish song Komm, komm, Papa (Sw. 'Come, come, Daddy'). ${ }^{29}$ Also the ornamented folk hymn singing likely follows the Swedish model. ${ }^{30}$

The Estonians in Hiiumaa used the same musical instruments that are listed as Swedish ones (bagpipe, bowed harp, violin, accordion, Jew's harp, simbel-kantele ${ }^{31}$, and horns) by Rußwurm (2015 [1855]: 453-473). The Swedes who settled on the western Estonian coast brought a bagpipe and a bowed harp (Sw. talharpa, Est. hiiurootsi kannel) with them, and the latter became popular especially among the Swedes on Vormsi Island. People still recall that the bowed harp was played both by Swedes and Estonians in Hiiumaa. Hiiumaa also had the longest vivid bagpipe tradition. Aleksander Maaker, an offspring of the last Estonian traditional bagpipe family, was an active musician in Hiiumaa until the 1960 s.

Ancient bagpipe tunes with triple meter and specific rhythmic patterns, discussed above, developed mainly in Swedish contact areas in northern and western Estonia. Some asemantic words in lyrics imitated, besides bagpipe sounds, words in Swedish (Rüütel 1983). Melodies close to Estonian bagpipe 
tunes and dance songs were likely known by Hiiumaa Swedes, because they had been collected from areas in Estonia inhabited by Swedes, mostly by Cyrillus Kreek from Vormsi Swedes in the 1920s (Kõlar 2010).

As Rüütel has proved, the popular labajalg type dance song Hiir hüppas ('The mouse jumped'), Examples 11b, 12) might date back to the seventeenth century or even earlier: the song was published already in the late eighteenth century, and its text had roots in a sixteenth-century Swedish song that spread both in Finland and Estonia. The melody of the Hiir hüppas type is related to a well known bagpipe tune family that spread in northern Estonia and on the islands (Rüütel 2012: 119-127). The song was known at least by some Estonian Swedes, as Rußwurm had notated an example of this song type from the Swedes in Vihterpalu, on the western coast of Estonia, in 1855.

\section{Example 12.}

Iir üppas, kass kargas, A mouse was jumping, a cat was bouncing, vana karu lõi trummi, an old bear was drumming, kerp aknast välja, flea, get out the window, nahk-püksid jalga. and put leather trousers on!

ERA II 254, 209 (2) < Emmaste p., Muda v. - Enda Ennist < Anna Kuru, b. 1863 (1939)

Katten slår uba tumman, fjŷra missar danssar, brämsen springar, hela werden dyndar!

(Rußwurm 2015 [1855]: 467)

\section{Saaremaa and Muhu islands}

Some parallels can be drawn between the song traditions of Hiiumaa and the neighboring Saaremaa and Muhu islands. The Swedish population lived in Saaremaa and on the western coast mainly during the fourteenth to sixteenth centuries and became assimilated earlier than the Swedes in Hiiumaa.

Changes in the formal features of the regilaul meter, such as the dropping of the 8th syllable at the end of a line or ignoring the syllable length, as well as the abundance of transitional songs at different stages of development, are 
described by the researchers as the features typical of the whole western Estonian song area, where the changes were more vivid as compared to the northern Estonian area (Rüütel 2012; Sarv 1998). While Hiiumaa regilaul has the most striking features of modernized syllabic-accentual regilaul meter, the next one in this top-list is its neighbor, Saaremaa Island (Sarv 2008: 26, 27, 39).

The vivid modernization process that Hiiumaa folk songs revealed to us occurred in a similar way in Saaremaa. Typical of the western coast tradition, Mustjala songs showed an abundance of transitional features: the syllabicaccentual meter and the end-rhymed verse pairs in regilaul and its successors. "The transitional forms between regilaul and end-rhymed song can be observed in very different developmental stages in Saaremaa" (Tampere \& Tampere 1985: 8-9). In Saaremaa and Hiiumaa older lyroepic songs disappeared during the same period, most probably in the mid-nineteenth century. Parallels can be drawn between the wedding songs: in eastern Hiiumaa and eastern Saaremaa the festive ritual style was known until the 1870s-1880s; more joking wedding songs and singers' contests occurred in western Saaremaa in the twentieth century and some examples thereof were observed in Hiiumaa (about Saaremaa see Rüütel 2015b: 23-29; Tampere \& Tampere 1985).

The neighboring Muhu Island represents a special song area (together with Pöide region in Saaremaa and some western continental parishes) with a different regilaul tradition in the western Estonian context. Although Muhu regilaul was already influenced by accentual-syllabic meter, the songs were closer to Kalevala-meter for their mostly 8-syllable verses, old word forms and use of the quantity principle (Oras 2001; Sarv 2008: 32, 35, 78). Muhu regilaul tradition was relatively extensive and the songs were performed during a longer period of time. The more modern Muhu songs with rhymed stanzas also contain features of alliterative songs (Rüütel 2015b: 8; 2016: 31-40).

On all the three islands the extensive male repertoire related to local life was popular as well as the bagpipe music and labajalg dance songs in triple meter, often used with frivolous texts (see Rüütel 2012: 130-138, maps 1-3; about Saaremaa and Muhu songs see Rüütel 2015a, 2015b, 2016). The common feature of Muhu and Mustjala children's songs is the abundance of labajalg dance music (Oras 1988; Tampere \& Tampere 1985), and the same can be said about Hiiumaa. 


\section{Other cultural contacts and influences}

Besides the direct impact of close neighbors, culture is definitely also indirectly influenced. These impacts can be mediated by neighbors, travelers, and sailors, printed sources, and other factors. Hiiumaa had direct overseas contacts with Finland and Scandinavia. Ingrid Rüütel suggests that dance songs labajalg represent a style of instrumental music from the Early Middle Ages, with an area of distribution extending from Estonia to Scandinavia and up to Ireland (Rüütel 1998: 66).

One reason for changes in the old traditions can be sailors' overseas contacts. In foreign harbors they heard and brought home new Western European song lore as well modern instruments. The hand harmonica had a great impact on the development of more modern songs with functional harmony. The instrument was played in Hiiumaa already in the 1890s by the men of Kerema village in Pühalepa parish (ETMM, M 221: 1/15, 10). Harri Otsa has mentioned: "The role of folk singers diminishes while the more modern song style emerges and develops, and will be replaced by an image of the singer-instrumentalist" (ETMM, M 221: 1/15, 3). Folk songs also received influences from printed sources. The folklore collections and diaries testify that the newer repertoire spread fast, and the round game songs and dances of newer styles dominated in young people's festivities in the early 1900s (cf. Rüütel 1980, 1983, 2015a, 2015b, 2016) ${ }^{32}$.

Another factor to produce musical change was pietistic movements (Brethren, Herrnhuters, Heaven Travelers, etc.), which were gaining popularity already in the early eighteenth century, especially in Lääne and Hiiu counties. The pietistic culture spread largely in these regions during the 1880s and Hiiumaa remained one of the centers of the Brethren movement in Estonia during the nineteenth century (Põldmäe 1988: 68). In these congregations pietistic songs were sung that rooted in the German and Swedish traditions. This musical style became popular and prestigious as it was close to local, already familiar, more modern folk songs (e.g. seamen's repertoire) and supported the quicker modernization of old folk songs (Plaat 2001: 393-407).

The folk song collectors, especially Enda Ennist, complained that fanatic Christians did not know or speak about old heritage, and had an overall hostile attitude towards the guests (ERA II 189, 61/2). ${ }^{33}$ Ingrid Rüütel also stresses that pietistic movement consciously displaced old traditions and discouraged regilaul from active use (Rüütel 2014). But conversely, over time, Christian music - for example Lutheran chorales - also adopted folk music features, folklorized, and developed melismatically variegated melodies (Lippus 2006: 45-46). 


\section{FINAL CONCLUSIONS}

The present study observed Hiiumaa older folk song tradition and its changing processes in local historical and cultural context, as well as analyzed the representability of written and sound-recorded folklore material available mainly in the Estonian Folklore Archives, the Estonian Theatre and Music Museum, and in some publications. The analysis was provoked by the question why Hiiumaa has a reputation of a poor regilaul area in the Estonian context. The reasons for the relatively small number of archived songs were searched in the history of folklore collecting and folk song tradition.

Hiiumaa is the second largest island off the western coast of Estonia, $22 \mathrm{~km}$ from the mainland. It had Swedish settlement from the thirteenth century and the heterogeneous settlement of Estonians, who had come from the neighboring western coastal regions and islands mainly in the sixteenth century. Because of the slow and peaceful assimilation of the two ethnic groups over a long period, their music traditions mutually influenced each other.

As a statistical survey on Hiiumaa older folk songs proves, the total amount of older folk songs (archaic vocal genres, regilaul, and older transitional songs) is relatively modest in the folklore sources - about 1430 song lyrics, about 280 of them with melodies. The folk song collections, with the first two examples dating from 1832 and more material from 1877 and up to 1979, are quite representative, except for the proportions of different song styles. By means of a formal comparative analysis of songs and contextual information from fieldwork diaries, the history of singing tradition was outlined back to the early 1800s. The history of folk song collecting started in Hiiumaa with Finnish scholar Carl A. Gottlund in 1832 and was continued by his countryman Oskar A. F. Mustonen (orthonym Lönnbohm) in 1877. The first Estonian collector in Hiiumaa was Madis Liedenberg in 1882, who was followed by a few correspondents after Hurt's appeal in 1888. The first large collection of folk songs with melodies was recorded by Peeter Süda and his colleagues in 1905-1906. The first sound recordings of Hiiumaa instrumental music were made in 1908 and those of folk songs in 1921. Extensive material was written down in the 1920 s-1930s. Several older and more modern songs were sound-recorded and written down during the Estonian Folklore Archives' expedition in 1979.

Interest in folklore was aroused and influenced mainly by national ideology; therefore it was preferred to record the older song tradition, especially regilaul. The collections reflect a somewhat earlier period than the "collector's present". Due to the value judgments and the availability of regilaul lyrics in Hiiumaa in 
the nineteenth century, they form $75 \%$ of the entire older song material of that period. The percentage of regilaul among older folk songs decreased abruptly, constituting only $41 \%$ in the first half and $8 \%$ in the second half of the twentieth century. The take of transitional songs and especially archaic vocal genres, the latter not being considered as the object of folkloristic interest until the early 1900 s, proportionally increased over time. The overall amount of Hiiumaa song variants is quite small due to the shortage of folklore collectors working on the island. The possible reasons for rare fieldwork and the small number of local correspondents were the location of Hiiumaa overseas, far from Tartu, the centre of the intelligentsia, and maybe lack of good examples of regilaul with formal features of Kalevala-metric poetry.

The folklore collections demonstrate the manifold singing tradition in the process of changing in Hiiumaa during the last one and a half centuries. The old and new song traditions, partly representing the different worldviews and opposite stylistic means, were known in Hiiumaa in the late nineteenth century: archaic magic spells, natural sound imitations, mythological regilaul songs, various children's joking songs existed side by side with modern ballads, waggish village chronicles, international seamen's songs, "improper" bagpipe songs, and soulful folk chorals.

Regilaul was somewhat modernized and had an accentual-syllabic meter likewise in the wider western Estonian area, from where the Hiiumaa inhabitants originated and with which they still had contacts. Regilaul was losing its prestigious position and function in the public sphere probably in the midnineteenth century and was forgotten among the younger generation by the 1920 s. Parallels can be drawn between, on the one hand, the more archaic folk song areas in Muhu and in the eastern parts of Hiiumaa and Saaremaa and, on the other hand, the more modernized western parts of Saaremaa and Hiiumaa with the Swedish population.

In the changing folk tradition transitional songs emerged - the new lyrical and narrative songs about local events, soldiers' and sailors' life, as well as several children's rhymes, which still partly used the same poetic means as older alliterative songs.

The local Swedish impact might have accelerated the changes in poetic means. The Swedish influence is especially manifest in Estonians' instrumental music (bagpipe and bowed harp tradition) and labajalg dance songs with humorous and obscene texts, which were sung to bagpipe pieces with various functions. The large number of labajalg dance songs and children's songs in triple meter reflects the pervasive impact of bagpipe music. The other factors 
for the faster adaption of more modern folk music in Hiiumaa could be international overseas contacts and the popularity of religious movements with their own music and contempt for earlier folk music.

In final conclusion, it can be said that the reasons why Hiiumaa is not represented by very numerous examples of older folk songs, especially regilaul, lie both in the history of folklore collecting and the processes that took place in the singing tradition. Hiiumaa regilaul song was declining, but still available in the late nineteenth century, when only a few collections were compiled on this remote island. Other older folk song styles did not belong to the collectors' sphere of interest because of the national-romantic bias in early folkloristics. So the slight interest in archaic vocal genres and transitional songs in the earlier periods of folklore collection, the lack of regilaul since the mid-twentieth century, the remote location of Hiiumaa, and the lack of local intelligentsia shaped the Hiiumaa folk song collections. The existing examples, if treated source-critically, still give an overall dynamic picture about the Hiiumaa folk song tradition in the process of stylistic and contextual changes.

\section{ACKNOWLEDGEMENTS}

This research was supported by the Centre of Excellence in Estonian Studies (CEES, European Regional Development Fund) and is related to research project IUT 22-4 "Folklore in the Process of Cultural Communication: Ideologies and Communities" (Estonian Ministry of Education and Research, Estonian Research Council).

\section{NOTES}

$1989 \mathrm{~km}^{2}, 9348$ inhabitants as of January 2016. http://www.stat.ee/ppe-44780, last accessed on April 26, 2017.

2 Sarv has constructed the areas on the basis of counties. The bigger western Estonian region is meant here; it comprises Lääne (Western) and Pärnu counties, and the islands of Saaremaa and Hiiumaa.

3 This kind of shortening is supported by the singer's need to draw breath after the verse or some verses if there does not exist archaic group singing with a lead singer and a chorus any more, in which the lead singer can draw breath during the verse repetition by the choir. 
4 Serfdom was abolished in northern Estonia in 1816 and in southern Estonia in 1819, but peasants kept working on manors if they could not afford to buy the land.

5 Flat foot waltz.

6 Text translations: No. 120: If it was said to me in a dream / given to know while dozing / that I should get a nasty wife / trouble for a bad spouse. No. 122, III: The instrument [bagpipe] says / the party is over, dear host. [---] EÜS II $822(120,121,122)<$ Reigi p., Pihlaka v. - Peeter Süda, Voldemar Quarnström < Juhan Teebak, 75 (1905).

7 The number of Hiiumaa lyroepic song types would be bigger if we had followed the classification of songs composed for Mustjala Parish, Saaremaa Island, by Tampere. The well-known songs of both islands, such as Kass kaevus ('The cat in the well'), Kubjas ja teomees ('The overseer and the serf'), and some more, are classified as lyroepic songs in Tampere \& Tampere (1985), but as lyrical songs by Tedre (1969-1974); the latter also served as a basis for our research.

8 Lunastatav neiu ('The maiden for ransom'). EÜS III 693 (3) (melody), EÜS III 713 (6) (lyrics) < Pühalepa p., Kassari v. - P. Süda, A. Sakkeus, K. Lember < Liisu Mets, 68 (1906).

9 The wedding song cycles, represented as one unit by a folklore collector, are not divided by the authors. Also some lyrical song types that might have occurred in a wedding ritual or outside it have not been added to the wedding songs, such as: Tule mulle ('Marry me'), Tare teretus ('The greeting of the house'), etc. They occur loosely outside the wedding cycle and are not commented on as wedding songs. If the folklore material was analyzed otherwise, the number of wedding songs would be bigger.

${ }^{10} 35$ songs are from Kassari Island, which is divided between Pühalepa and Käina parishes; 13 from eastern Hiiumaa coastal areas in the same parishes. All the 5 melody variants are also from the same area. Only 9 examples are from Emmaste Parish, none from Reigi Parish, and seven are of unknown origin.

${ }^{11}$ One exceptional fragment originates from 1979. RKM II 339, 323/8 < Käina p. - Erna Tampere < Amalie Onno, b. 1909 (1979).

12 EÜS II 841 (175) < Käina p. - Peeter Süda < Toomas Jõekald, 54 (1905).

${ }^{13}$ EÜS III 694 (5) < Pühalepa p., Allika v. - Peeter Süda < Tiiu Kruusimägi (1906).

14 The number of imitations and incantations is approximate because the border between a linguistic phraseological unit and a sound imitation as a genre of vocal music, as well as the border between a magic formula and an incantation, is not clearly fixed, and because all the narratives and song lyrics have not been searched through in order to find them.

${ }^{15}$ RKM, Mgn II 3124 (10b) < Pühalepa p., Tubala v. - Anne Tael, Sirje Sarapuu < Helene Põldver, b. 1900 (1979).

${ }^{16}$ RKM, Mgn II 3698 (18) < Pühalepa p., Kärdla town - Einar Sinijärv < Ella Erk, b. 1924 (1979). 
${ }^{17}$ RKM, Mgn II 3163 (12) < Emmaste p., Viiri v. - Erna Tampere < Alma Vesmes, b. 1906 (1979).

${ }^{18}$ RKM, Mgn II 3129 (6) < Reigi p., Kaleste v. - Anu Zirk, Edna Lips < Eduard Pihel, 76 (1979).

${ }^{19}$ Another short variant without the refrain is in H II 41, 146 (4) < Pühalepa p. - Gustav Tikerpuu (1888).

${ }^{20}$ RKM, Mgn II 3133 (35) < Pühalepa p., Kõpu v. - Anu Zirk, Edna Lips < Elli Küttim, b. 1909 (1979). The printed text begins: "Vaat kaugel laias laanes ju kägu kukub sääl..." ('A cuckoo is cuckooing afar in a large woodland...') The song was first published in a monthly Laulu ja mängu leht ('Newsletter of singing and music') in 1888, and later in several songbooks, for example, Riho Päts' Lemmiklaulik ('Favorite song book') in 1937.

${ }^{21} 13$ sound-recordings made from Juuli Küttim in 1962 were published on a CD in 2007 (Saard 2007).

${ }^{22}$ Kristi Salve (1997: 478) has found similar long parallelism groups, containing also many place names, in Vepsian alliterative songs without Kalevala-meter, and posed the question whether these can be pre-regilaul structures. The problem cannot be solved in the present study.

${ }^{23}$ There is a vowel in Hiiumaa dialects which is in between Estonian /ö/ and /e/; the collector has transcribed it as 'e'. Therefore, the written word looks like tee 'road, way', but its more logical meaning according the context is töö 'work'.

${ }^{24}$ Liisapunt - Lisbon. Leegerpung (Le Grand Port) and Portugal - two harbors side by side on the coast of western France (Päll 1999). Portugüüs - Português (a harbor in France).

25 The dance song Leerimetsa Vahi-Peeter, played by Jüri Koid on kannel (zither), EÜS II 817 (101 A); violin pieces, played by Gustav Alas, EÜS III 699 (19, 23, 24) (melodies); EÜS III 723 (14) (lyrics).

${ }^{26}$ Translations of the semantic parts of lyrics: Ex. 9. Missus, missus, / shinbone, shinbone. / One missus, other shinbone, / one felt mitten, other [knitted] mitten. Ex. 10. Our Mart, turn yourself over Kreet. / One behind another, / Mats behind Mare, / behind a heap of stones, / behind Pihla inn. / Pushed Anne down, put the bell behind (RKM, Mgn II 3133 (7a, 6) < Reigi p., Kõpu v. - Anu Zirk, Edna Lips < Elli Küttim, b. 1909 (1979)).

${ }^{27}$ Today the dance songs tradition in Hiiumaa is being kept alive and popular by a folk group Iiukala Bänd, who has learned many pieces from the sound recordings of Elli Küttim, Aare Elend, etc. (Iiukala 2013). See https://iiukalaband.wordpress.com/ tutvustus/, last accessed on April 28, 2017.

${ }^{28}$ Translation: a) Pat a loaf, smear butter on it! b) A mouse was jumping, / a cat was bouncing, / an old bear was drumming, / it broke the drum, / and had to pay a fine of 100 rubles. RKM, Mgn II 3135 (9a, b; 6) < Reigi p., Mägipe v. - Erna Tampere < Juuli Küttim, b. 1909 (1979). 
${ }^{29}$ ERA II 189, 69 (63) < Emmaste p. - Enda Ennist < Siim Muda, b. 1863 (1938), called a lullaby by the singer.

${ }^{30}$ Urve Lippus has compared the Estonian and Estonian Swedish folk hymn repertoires and analyzed Cyrillus Kreek's and Peeter Süda's folk hymn collections (Lippus 2006: 41).

${ }^{31}$ Simbel - newer bigger diatonic kantele.

${ }^{32}$ A few of the Hiiumaa songs in folklore collections are related to printed sources: a dance song Vaat lupsadi (H III 5, 147 (10) < Pühalepa p., Kärdla town - A. C. F. G. (1888)), and two songs recorded in 1979: Kiigu, liigu, laevukene ('Swing, sway, dear ship') (RKM, Mgn II 3127 (5) < Pühalepa p., Valipe v. - Erna Tampere, Mart Jallai, Jaak Elling < Marie Tülp, 80 (1979); RKM, Mgn II 3133 (25) < Pühalepa p., Kõpu v. - Anu Zirk, Edna Lips < Elli Küttim, b. 1909 (1979)), and a cuckoo's song imitation, added as a refrain to a French canon (published in 1888).

${ }^{33}$ Enda Ennist, fieldwork diary, 1939.

\section{ARCHIVAL SOURCES}

\section{Collections of the Estonian Folklore Archives at the Estonian}

\section{Literary Museum}

E, StK - manuscript collection of Matthias Johann Eisen's grantees (1921-1927) ERA - manuscript collection of the Estonian Folklore Archives (1927-1944)

ERA, Fon - wax cylinders collection of the Estonian Folklore Archives (1912-1948)

EÜS - manuscript collection of the Estonian Students Society (1875-1917)

$\mathrm{H}$ - manuscript collection of Jakob Hurt (1860-1906)

RKM - manuscript collection of the Estonian State Literary Museum (1945-1996)

RKM, Mgn - collection of open-reel tape recordings of the Estonian State Literary Museum (1945-1996)

\section{Collections of the Estonian Theatre and Music Museum}

ETMM, M 221: 1/15 - Harri Otsa's manuscript Hiiumaa uus rahvalaul ('The modern folk song of Hiiumaa') 2001

ETMM, M 234: 1/14-28 - August Pulst's manuscript Mälestusi muusika alalt ('Memories from the field of music') 1961 


\section{REFERENCES}

Gottlund, Carl Axel 1832. Keännöksiä Viron kielestä. [Translations from the Estonian Language.] In: Otava eli suomalaisia huvituksia II. [Great Bear and Finnish Entertainment Venues.] Stockholm: M. B. Bredbergin kirja-paja, pp. 181-193. Available at http://www.doria.fi/bitstream/handle/10024/58997/p49-06_f406675. pdf?sequence=1, last accessed on April 25, 2017.

Hedman, Jörgen 2015. Rootslaste asustus. [The Swedish Settlement.] In: Helgi Põllo (ed.) Hiiumaa: Loodus, aeg, inimene. Kärdla: Hiiumaa teabekapital, pp. 801-812.

Iiukala 2013 = Iukala Bänd. Tee oli ränkas... [The Road was Gravelly...] Kärdla. CD.

Kaskor, Vello 2015. Asustuse kujunemine ja rahvastik läbi aegade. [The Development of Settlement and Population over Time.] In: Helgi Põllo (ed.) Hiiumaa: Loodus, aeg, inimene. Kärdla: Hiiumaa teabekapital, pp. 787-800.

Kõlar, Anu 2010. Cyrillus Kreek ja Eesti muusikaelu. [Cyrillus Kreek and Musical Life in Estonia.] Diss. (PhD Thesis). Eesti Muusikaakadeemia väitekirjad 5. Tallinn: Eesti Muusika- ja Teatriakadeemia. Available at http://www.digar.ee/arhiiv/et/ raamatud/61094, last accessed on May 4, 2017.

Kõmmus, Helen \& Särg, Taive 2017. Star Bride Marries a Cook: The Changing Processes in the Oral Singing Tradition and in Folk Song Collecting on the Western Estonian Island of Hiiumaa. I. Folklore: Electronic Journal of Folklore, Vol. 67, pp. 93-114. http://dx.doi.org/10.7592/FEJF2017.67.kommus_sarg.

Lippus, Urve 2006. The Estonian Tradition of Folk Hymn Singing. In: Kirsten Sass Bak \& Svend Nielsen (eds.) Spiritual Folk Singing: Nordic and Baltic Protestant Traditions. Copenhagen: Forlaget Kragen, pp. 41-65.

Lönnbohm, Oskar Anders Ferdinand [Mustonen, O.A.F.] 1893. Virolaisia kansanrunoja / Vihukene Eesti rahva laulusid. [Estonian Folk Songs.] Helsinki: Suomalaisen kirjallisuuden seuran kirjapaino.

Oras, Janika 1988. Muhu lastelaulude viisid. [Melodies of Muhu Children's Songs.] Diploma work. Manuscript at the Department of Estonian and Comparative Folklore, University of Tartu.

Oras, Janika 2001. Muhu regilaulude rütmid. [The Rhythms of Muhu Runo Songs.] In: Tiiu Jaago \& Mari Sarv (eds.) Regilaul - keel, muusika, poeetika. Tartu: EKM Teaduskirjastus, pp. 153-194.

Päll, Peeter 1999. Maailma kohanimed. [Toponyms of the World.] Tallinn: Eesti Keele Sihtasutus. Available at https://www.eki.ee/knab/mkn_ind.htm, last accessed on May 19, 2017.

Plaat, Jaanus 2001. Usuliikumised, kirikud ja vabakogudused Lääne- ja Hiiumaal: usuühenduste muutumisprotsessid 18. sajandi keskpaigast kuni 20. sajandi lõpuni. [The Religious Movements, Churches and Free Congregations in Läänemaa and Hiiumaa: The Changing Processes of Religious Organisations from the Mid-18th Century to the End of the 20th Century.] Tartu: Eesti Rahva Muuseum. 
Põldmäe, Rudolf 1988. Vennastekoguduse muusikalisest tegevusest meie maal. [About the Musical Activity of Brethren Congregation in Our Country.] Teater. Muusika. Kino, No. 3, pp. 67-78.

Rußwurm, Carl 2015 [1855]. Eibofolke ehk rootslased Eestimaa randadel ja Ruhnus. [Eibofolke oder die Schweden an den Küsten Ehstlands und auf Runö.] Transl. by Ivar Rüütli. Haapsalu: MTÜ Eestirootsi Akadeemia.

Rüütel, Ingrid 1980. Eesti uuemad laulumängud I. [Estonian More Modern Song Games I.] Tallinn: Eesti Raamat.

Rüütel, Ingrid 1983. Eesti uuemad laulumängud II. [Estonian More Modern Song Games II.] Tallinn: Eesti Raamat.

Rüütel, Ingrid 1998. Estonian Folk Music Layers in the Context of Ethnic Relations. Folklore: Electronic Journal of Folklore, Vol. 6, pp. 32-69. http://dx.doi.org/10.7592/ FEJF1998.06.ruutel.

Rüütel, Ingrid 2012. Eesti uuema rahvalaulu kujunemine. [The Evolvement of Estonian More Modern Folk Song.] Tartu: EKM Teaduskirjastus.

Rüütel, Ingrid 2014. Hiiumaa rahvamuusikast. [About Hiiumaa Folk Music.] Unpublished manuscript in possession of the author.

Rüütel, Ingrid 2015a. Muhu rahvamuusikat, laulumänge ja tantse. [Traditional Music, Song Games and Dances of Muhu Island.] Helisalvestusi Eesti Rahvaluule Arhiivist 9. [Recordings from the Estonian Folklore Archives 9.] Tartu: EKM Teaduskirjastus.

Rüütel, Ingrid 2015b. Saaremaa laule ja lugusid. [Songs and Tales of Saaremaa.] Tartu: EKM Teaduskirjastus.

Rüütel, Ingrid 2016. Muhumaa laule ja lugusid. [Songs and Tales of Muhu.] Tartu: EKM Teaduskirjastus.

Saard, Riho 2007. Ühe lae pealt teise lae peale. [From One Ceiling to Another Ceiling.] CD. In: Mägipe ja Suurepsi: Kõpu poolsaare taevased külad. Tallinn: Infotrükk.

Salve, Kristi 1997. Mõtteid vepsa rahvalaulust. [Reflections on Vepsian Folk Song.] Keel ja Kirjandus, Vol. 7, pp. 470-480. Available at http://www.digar.ee/arhiiv/ et/perioodika/35028, last accessed on May 4, 2017.

Salve, Kristi \& Sarv, Vaike 1987. Setu lauludega muinasjutud. [Setu Fairy Tales with Songs.] Tallinn: Eesti NSV Teaduste Akadeemia, Keele ja Kirjanduse Instituut.

Sarv, Mari 1998. Language and Poetic Metre in Regilaul. Folklore: Electronic Journal of Folklore, Vol. 7, pp. 87-107. http://dx.doi.org/10.7592/FEJF1998.07.maripar.

Sarv, Mari 2008. Loomiseks loodud: Regivärsimõõt traditsiooniprotsessis. [Created for Creation: Verse Metre of Estonian Regilaul in the Tradition Process.] Tartu: Tartu Ülikooli Teaduskirjastus. Available at http://dspace.ut.ee/handle/10062/5358, last accessed on May 4, 2017.

Sarv, Mari 2011. Language or Culture? Possible Foreign Influences on the Estonian Regilaul Metrics. In: Mihhail Lotman \& Maria-Kristiina Lotman (eds.) Frontiers in Comparative Prosody: In Memoriam Mikhail Gasparov. Bern \& Berlin \& Brussels \& Frankfurt am Main \& New York \& Oxford \& Wien: Peter Lang Verlag, pp. 207-226. 
Tampere, Herbert \& Tampere, Erna 1985. Vana Kannel V: Mustjala regilaulud. [The Old Psaltery V: Regilaul from Mustjala Parish.] Monumenta Estoniae antiquae I: Carmina Popularia V. Tallinn: Eesti Raamat.

Tedre, Ülo (ed.) 1969-1974. Eesti rahvalaulud I-IV: Antoloogia. [Estonian Folk Songs: Anthology.] Tallinn: Eesti Raamat.

Helen Kõmmus is researcher of folklore and ethnomusicology at the Estonian Folklore Archives of the Estonian Literary Museum, Estonia, and a PhD student of ethnomusicology at the University of Tampere.

helen@folklore.ee

Taive Särg, $\mathrm{PhD}$ in Estonian and comparative folklore (University of Tartu, 2005), is a senior research fellow at the Estonian Folklore Archives of the Estonian Literary Museum, Estonia.

taive@folklore.ee 